\title{
A coumarin-based colorimetric fluorescent probe for hydrogen sulfide
}

\author{
YANQIU YANG ${ }^{\mathrm{a}}$, YU LIU ${ }^{\mathrm{b}}, \mathrm{LIANG}_{\text {YANG }}^{\mathrm{a}}$, JUN LIU ${ }^{\mathrm{a}}, \mathrm{KUN} \mathrm{LI}^{\mathrm{b}, *}$ and SHUNZHONG LUO ${ }^{\mathrm{a}, *}$ \\ ${ }^{a}$ Institute of Nuclear Physics \& Chemistry, CAEP, Mianyang, Sichuan Province, China, 621900 \\ ${ }^{\mathrm{b}}$ College of Chemistry, Sichuan University, Chengdu, Sichuan Province, China, 610064 \\ e-mail: luoshzh@caep.ac.cn; kli@scu.edu.cn
}

MS received 5 September 2014; revised 30 October 2014; accepted 23 December 2014

\begin{abstract}
A coumarin-based fluorescent probe for selective detection of hydrogen sulfide $\left(\mathrm{H}_{2} \mathrm{~S}\right)$ is presented. This 'off-on' probe exhibited high selectivity towards $\mathrm{H}_{2} \mathrm{~S}$ in aqueous solution with a detection limit of $30 \mathrm{nM}$. Notably, because of its dual nucleophilicity, the probe could avoid the interference of thiols and other sulfur containing compounds.
\end{abstract}

Keywords. Coumarin; reactive probe; $\mathrm{H}_{2} \mathrm{~S}$ probe

\section{Introduction}

Hydrogen sulfide $\left(\mathrm{H}_{2} \mathrm{~S}\right)$ is an endogenously produced gaseous signalling compound (gasotransmitter), along with nitric oxide (NO) and carbon monoxide (CO), which mediate a wide range of physiological and pathological effects, such as anti-oxidation, anti-inflammation, apoptosis, etc. ${ }^{1-3}$ Due to the important role of $\mathrm{H}_{2} \mathrm{~S}$, developing a sensitive, rapid, and reliable detection technique for it is in high demand and has become a hot research area in the past few years. Many excellent fluorescent probes for the detection of $\mathrm{H}_{2} \mathrm{~S}$ have been reported based on different strategies including $\mathrm{H}_{2} \mathrm{~S}$ mediated reduction of azide and nitro compounds, ${ }^{4,5}$ an azamacrocyclic copper(II) ion complex, ${ }^{6}$ thiolysis of dinitrophenyl ether, ${ }^{7}$ and $\mathrm{H}_{2} \mathrm{~S}$ trapping by nucleophilic addition. ${ }^{8}$ The nucleophilic reactions of $\mathrm{H}_{2} \mathrm{~S}$ toward $\alpha, \beta$-unsaturated acrylate methyl ester or an aldehyde group have been widely used to design $\mathrm{H}_{2} \mathrm{~S}$-targeted chemodosimeters. The diversity of the reaction sites is beneficial for the design of fluorescence sensors, which result in ON-OFF, OFF-ON or ratiometric probes. ${ }^{8}$ But the selectivity and interference from other thiols (such as cysteine, homocysteine and glutathione) are still a challenge. Meanwhile, most of the probes need organic solvents as co-solvent, which improve the solubility of the probes or shorten the reaction time. To overcome the problems mentioned above, two-step nucleophilic reaction was introduced when designing probes for $\mathrm{H}_{2} \mathrm{~S}$, which exhibit promising future with good anti-interference. ${ }^{9}$ More recently, Guo group exploited 2-(iodomethyl) benzoate as a new $\mathrm{H}_{2} \mathrm{~S}$ trap group,

\footnotetext{
*For correspondence
}

and reported a fluorescein based probe for $\mathrm{H}_{2} \mathrm{~S}$ with high selectivity. ${ }^{9 \mathrm{e}}$ Inspired by this work, we wanted to develop a coumarin-based $\mathrm{H}_{2} \mathrm{~S}$ probe with similar mechanism.

Coumarin has been largely utilized as fluorophore in various fluorescent probes due to its large Stokes shift, good solubility and high quantum yield. ${ }^{10}$ Previously, we reported a coumarin-based chromogenic and ratiometric probe for hydrazine. ${ }^{11}$ As we know, when the phenolic hydroxyl of a fluorophore is protected via esterification, no emission of the fluorophore would be found due to the electron-withdrawing property of acetate group. However, the removal of ester groups under suitable condition will lead to the fluorescence recovery of the fluorophore. Herein, we designed a two-step nucleophilic reaction-based $\mathrm{H}_{2} \mathrm{~S}$ probe, which employs 7-hydroxy-coumarin as fluorophore by protecting the hydroxyl via an ester group.

The fluorescent probe was generally constructed with a 7-hydroxy-coumarin as fluorophore and 2-(iodomethyl) benzoate as $\mathrm{H}_{2} \mathrm{~S}$ trap that has two electrophilic reaction sites. The initial nucleophilic attack of $\mathrm{H}_{2} \mathrm{~S}$ would lead to an intermediate thiol, which spontaneously undergoes a cyclization by forming benzo[c]thiophen-1 $(3 H)$ one and releases the fluorophore thereby eliciting the obvious fluorescent signal (scheme 1).

\section{Experimental}

\subsection{General}

${ }^{1} \mathrm{H}$ NMR, ${ }^{13} \mathrm{C}$ NMR spectra were measured on a Bruker AM400 NMR spectrometer. ESI-MS and HRMS spectral data were recorded on a Finnigan LCQDECA and 


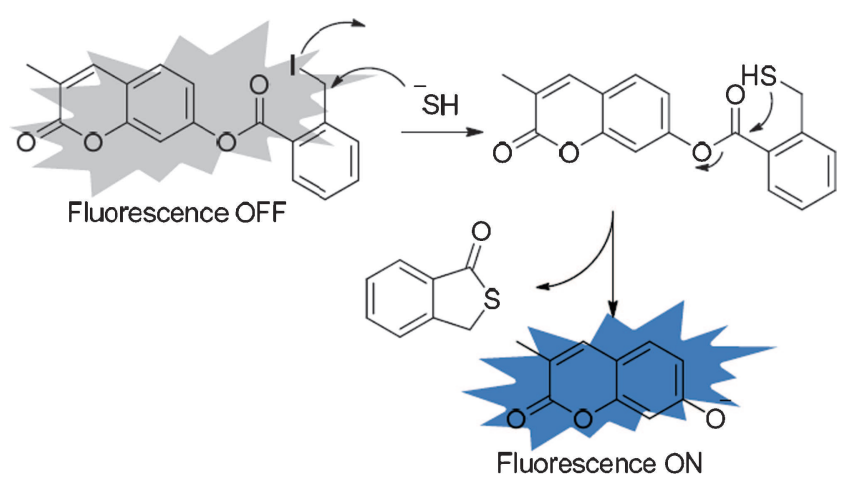

Scheme 1. The proposed sensing mechanism of probe $\mathbf{1}$ for $\mathrm{H}_{2} \mathrm{~S}$.

a BrukerDaltonics Bio TOF mass spectrometer, respectively. Fluorescence emission spectra were obtained using FluoroMax-4Spectrofluorophotometer (HORIBA JobinYvon) at $298 \mathrm{~K}$. Unless otherwise noted, materials were obtained from commercial suppliers and were used without further purification. All the solvents were dried according to the standard methods prior to use. All the solvents were either HPLC or spectroscopic grade in the optical spectroscopic studies.

\subsection{Synthesis of 2-iodomethylbenzoic acid ${ }^{9 e}$}

A solution of phthalide $(1.34 \mathrm{~g}, 10 \mathrm{mmol})$ and iodotrimethylsilane $(3.00 \mathrm{~g}, 15 \mathrm{mmol})$ in $\mathrm{CH}_{2} \mathrm{Cl}_{2}(15 \mathrm{~mL})$ was refluxed for $3 \mathrm{~h}$, cooled to room temperature, quenched with water $(10 \mathrm{~mL})$ and the precipitate was filtered off, washed with water to give a white solid (2.4 g, 90\%). The crude product was used directly without further purification.

\subsection{Synthesis of 7-hydroxy-3-methyl-coumarin ${ }^{12}$}

2, 4-dihydroxybenzaldehyde ( $6.0 \mathrm{~g}, 43.2 \mathrm{mmol})$, sodium propionate $(9.0 \mathrm{~g}, 93.6 \mathrm{mmol})$ and propionic anhydride $(15 \mathrm{~mL}, 117 \mathrm{mmol})$ were placed in a $100 \mathrm{~mL}$ roundbottom flask. Triethylamine $(6 \mathrm{~mL}, 43.2 \mathrm{mmol})$ was then added via the addition funnel, and the reaction mixture was heated to reflux for $6 \mathrm{~h}$. After the reaction, water $(30 \mathrm{~mL})$ was poured and the resulting pink solid was collected by filtration and washed with cold water. Column chromatography (ethyl acetate: petroleumether
$=1: 4$ ) of the crude product over silica gel gave a colourless powder. Yield: $3.63 \mathrm{~g}(47.7 \%)$.

\subsection{Synthesis of probe 1}

To a solution of DCC $(0.206 \mathrm{~g}, 1 \mathrm{mmol})$ in $\mathrm{CH}_{2} \mathrm{Cl}_{2}$ $(10 \mathrm{~mL})$ cooled at $0^{\circ} \mathrm{C}$ was added 2-iodomethylbenzoic acid $(0.262 \mathrm{~g}, 1 \mathrm{mmol})$ followed by DMAP (4-dimethylaminopyridine, $0.012 \mathrm{~g}, 0.1 \mathrm{mmol}$ ) and 7-hydroxy-3methyl-coumarin $(0.176 \mathrm{~g}, 1 \mathrm{mmol})$. The mixture was stirred at room temperature for $6 \mathrm{~h}$ and then filtered, washed with $\mathrm{CH}_{2} \mathrm{Cl}_{2}$. The filtrate was concentrated to afford the crude product, then purified by silica gel column chromatography (PE: EA $=20: 1$ ) to afford a white solid $(0.15 \mathrm{~g}, 36 \%)$. ${ }^{1} \mathrm{HNMR}(400 \mathrm{MHz}$, $\left.\mathrm{CDCl}_{3}\right) \delta(\mathrm{ppm}): 8.21(\mathrm{dd}, 1 \mathrm{H}, J=8.0 \mathrm{~Hz}, 1.0 \mathrm{~Hz}), 7.57$ $(\mathrm{s}, 2 \mathrm{H}), 7.527-7.507(\mathrm{~m}, 2 \mathrm{H}), 7.473-7.432(\mathrm{~m}, 1 \mathrm{H})$, $7.30-7.295(\mathrm{~m}, 1 \mathrm{H}), 7.252(\mathrm{dd}, 1 \mathrm{H}, J=8.0 \mathrm{~Hz}, 2.0$ $\mathrm{Hz}), 4.987$ (s, 2H), 2.261-2,258 (s, 3H). ${ }^{13} \mathrm{C}$ NMR $\left(100 \mathrm{MHz} \mathrm{CDCl}_{3}\right) \delta(\mathrm{ppm}): 164.5,161.8,153.8,152.0$, $142.4,138.7,133.7,132.1,131.5,128.3,127.7$, $126.9,125.4,118.5,117.6,110.3,17.2,3.4$. HRMS: $m / z \mathrm{C}_{18} \mathrm{H}_{13} \mathrm{INaO}_{4}^{+} \mathrm{Calcd} 442.9756$, found 442.9758 .

\subsection{Determination of the fluorescence quantum yield}

In this paper, the fluorescence quantum yields of probe 1 in the presence and absence of $\mathrm{H}_{2} \mathrm{~S}$ were determined in PBS buffer $(10 \mathrm{mM}, \mathrm{pH} 7.4$, containing $1 \mathrm{mM}$ CTAB), using quinine sulfate $(\Phi=0.542)$ as standard. The fluorescence quantum yield was calculated using the following equation:

$$
\Phi_{\mathrm{x}}=\Phi_{\mathrm{s}}\left(\mathrm{A}_{\mathrm{s}} \mathrm{F}_{\mathrm{x}} / \mathrm{A}_{\mathrm{x}} \mathrm{F}_{\mathrm{s}}\right)
$$

where, $A x$ and $A s$ are the absorbance of the sample and the reference, respectively, at the same excitation wavelength, $F_{x}$ and $F_{S}$ are the corresponding relative integrated fluorescence intensities. Absorbance of sample and reference at their respective excitation wavelengths was controlled to be lower than 0.05 .

\section{Results and Discussion}

3-methyl-coumarin-7-yl 2-(iodomethyl)benzoate (probe 1) could be easily prepared by the reaction of 7-hydroxy-<smiles></smiles>

Scheme 2. Synthesis of probe $\mathbf{1}$. 
3-methyl-coumarin with 2-(iodomethyl)benzoic acid in $\mathrm{CH}_{2} \mathrm{Cl}_{2}$ at room temperature in a yield of $36 \%$ (scheme 2). Its structure was further confirmed by ${ }^{1} \mathrm{H}$ NMR, ${ }^{13} \mathrm{C}$ NMR and HRMS. 7-hydroxy-3-methylcoumarin with 2-(iodomethyl) benzoic acid were synthesized according to the literature. ${ }^{9 e, 12}$

Firstly, we investigated the properties of probe $\mathbf{1}$ in PBS buffer. However, because of the poor solubility of probe $\mathbf{1}$, only 10 -fold fluorescence intensity enhancement was observed in the presence of large quantity $\mathrm{H}_{2} \mathrm{~S}$ (100 eq). Considering that the addition of excessive organic solvent might restrict the practical application of the probes, we envisioned that a rationally chosen micelle system could be substituted for the DMSO-PBS mixture. In the past decade, surfactants have been explored for modifying and improving the sensing capability of fluorescent probes. ${ }^{13}$ To explore the optimum condition of fluorescent turn-on probe for $\mathrm{H}_{2} \mathrm{~S}$, cetyl trimethyl ammonium bromide (CTAB) was utilized to improve the solubility. We first evaluated the effect of CTAB concentration on the fluorescence of the probe. As shown in figure $\mathrm{S} 1$, the thiolysis reaction is restricted without CTAB, and upon increasing CTAB concentration, the reaction becomes fast and more than 60 -fold fluorescence enhancement was achieved. The reaction is complete within $1 \mathrm{~min}$ using $1 \mathrm{mM} \mathrm{CTAB}$ (figure $\mathrm{S} 1$ ). The $\mathrm{pH}$ value also could affect the process (figure S2). The result showed that the action of the probe is rapid and highly sensitive selective for detection of hydrogen sulfide under optimum condition $(10 \mathrm{mM}$ PBS, pH 7.4, containing 1 mM CTAB). Acidic condition inhibits ionization of hydrogen sulfide, while probe is easy to hydrolyze under alkaline condition.

Then the selectivity of the probe was tested. As expected, probe 1 exhibited high selectivity towards $\mathrm{H}_{2} \mathrm{~S}$ over other biologically relevant reactive sulfur (RSS), oxygen (ROS) and reactive nitrogen species (RNS) under the same conditions. As shown in figure 1, most anions, ROS and RNS showed absolutely no change in the emission intensity compared with probe $\mathbf{1}$. Other abundant thiols in cells, such as glutathione and cystein, due to the absence of the dual nucleophilicity, they could not perform a second nucleophilic addition and exhibited limited fluorescence responses (100 eq. GSH or Cys). Additionally, a blue colour change was also observed in the presence of $\mathrm{H}_{2} \mathrm{~S}$ under UV light $(365 \mathrm{~nm})$. These results proved that probe 1 displayed excellent selectivity for $\mathrm{H}_{2} \mathrm{~S}$ over other abundant representative anions.

The time-dependent fluorescence spectra were then examined in the presence and absence of $\mathrm{H}_{2} \mathrm{~S}$ (figure S3). The results indicated that the process could be completed within $15 \mathrm{~min}$ with approximately 65 -fold

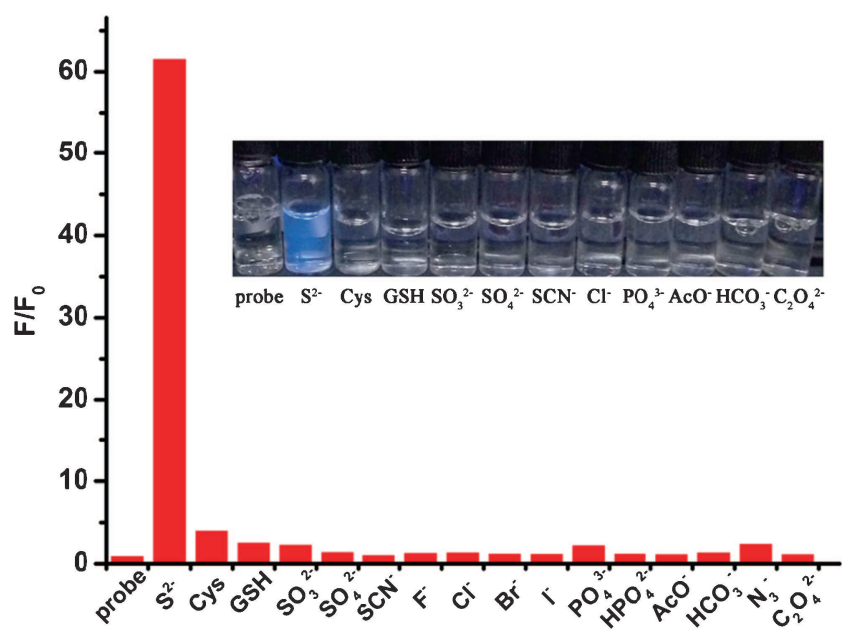

Figure 1. Fluorescence response of probe $1(5 \mu \mathrm{M})$ upon addition of various species in PBS buffer $(10 \mathrm{mM}, \mathrm{pH} 7.4$, containing $1 \mathrm{mM} \mathrm{CTAB})$. $\lambda \mathrm{ex}=350 \mathrm{~nm}, \lambda \mathrm{em}=466 \mathrm{~nm}$.

fluorescence enhancement. The fluorescence quantum yield $(\Phi)$ of probe $\mathbf{1}$ was determined as 0.04 in the absence of $\mathrm{H}_{2} \mathrm{~S}$, and improved to 0.66 after incubation $10 \mathrm{~min}$ in the presence of $\mathrm{H}_{2} \mathrm{~S}$.

More information on the optical responses of probe 1 towards $\mathrm{H}_{2} \mathrm{~S}$ was then studied using UV-Vis spectrum (figure S4). Probe $\mathbf{1}$ showed a moderately strong maximum absorption peak centred at $306 \mathrm{~nm}$ and the molar extinction coefficient values were determined as $1.6 \times 10^{4} \mathrm{M}^{-1} \cdot \mathrm{cm}^{-1}$. Upon addition of $\mathrm{H}_{2} \mathrm{~S}$, this peak gradually decreased and red shifted to a new absorption band centred at $314 \mathrm{~nm}$, which could be attributed to the removal of 2-iodomethylbenzoic acid group from probe 1. To further confirm our proposed mechanism, HRMS was used to investigate the reaction process. After the reaction, the peak at 199.0368 was assigned as $[\mathrm{M}+$ $\mathrm{Na}^{+}$(calc. 199.0371, figure S5).

Subsequently, the quantitative analytical behaviour of probe 1 for the analysis of $\mathrm{H}_{2} \mathrm{~S}$ was examined by fluorescence titration. As displayed in figure 2, upon gradual addition of $\mathrm{H}_{2} \mathrm{~S}$ to the probe, the emission intensity at around $466 \mathrm{~nm}$ increased significantly, while no change was found when 5 eq. $\mathrm{H}_{2} \mathrm{~S}$ or more was added. A good linear relationship was achieved with the $\mathrm{H}_{2} \mathrm{~S}$ concentration from 0 to $25 \mu \mathrm{M}$ (figure $\mathrm{S} 6$ ), and the limit of detection (LOD) was calculated as $30 \mathrm{nM}$ based on $\mathrm{S} / \mathrm{N}=3$.

To further confirm the selectivity of this fluorescent probe for hydrogen sulphide, the competition experiments were performed in the presence of various anions. As displayed in figure 3, a similar fluorescence change was observed upon addition of 5 eq. $\mathrm{H}_{2} \mathrm{~S}$ in the presence of various anions (100 eq.), such as $\mathrm{SO}_{3}^{2-}$, $\mathrm{SO}_{4}^{2-}, \mathrm{SCN}^{-}, \mathrm{F}^{-}, \mathrm{Cl}^{-}, \mathrm{Br}^{-}, \mathrm{I}^{-}, \mathrm{PO}_{3}^{3-}, \mathrm{HPO}_{4}^{2-}, \mathrm{AcO}^{-}$, $\mathrm{HCO}_{3}^{-}, \mathrm{N}_{3}^{-}, \mathrm{C}_{2} \mathrm{O}_{4}^{2-}$. Meanwhile, probe 1 displayed 


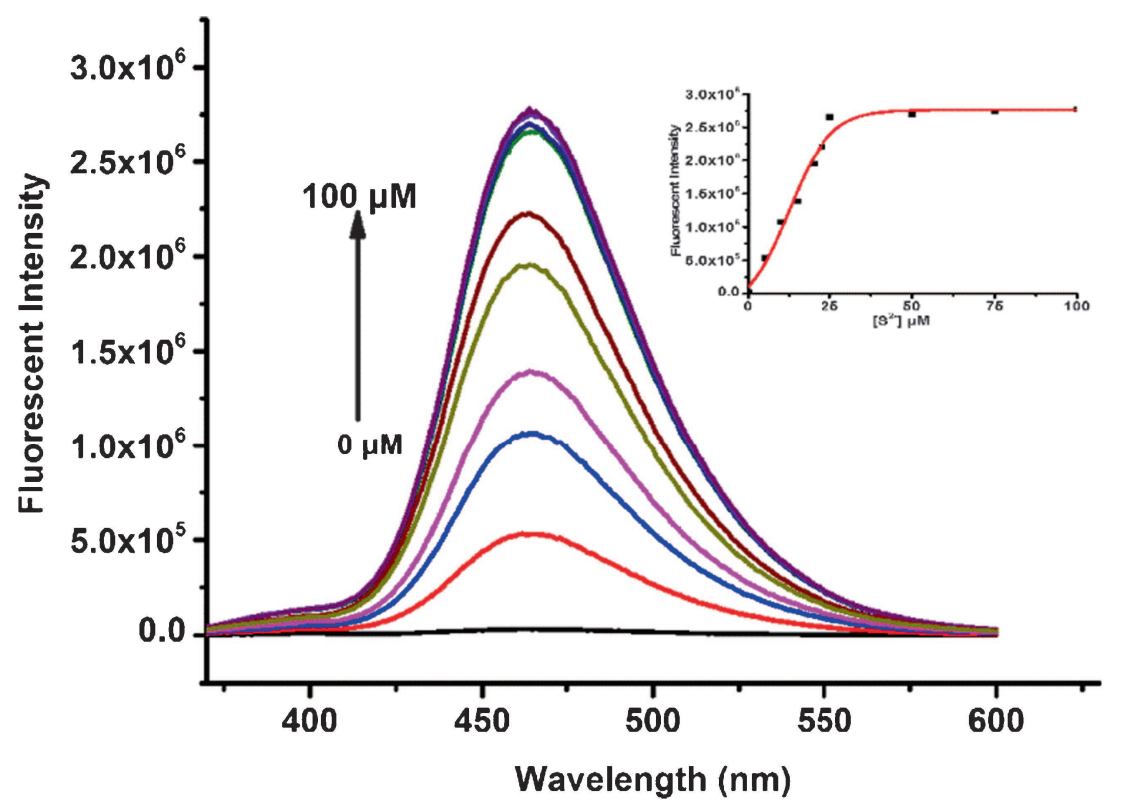

Figure 2. Fluorescence spectra of probe $1(5 \mu \mathrm{M})$ upon addition of $\mathrm{H}_{2} \mathrm{~S}(0-$ $100 \mu \mathrm{M})$ in PBS buffer (10 mM, pH 7.4,containing $1 \mathrm{mM} \mathrm{CTAB}) . \lambda \mathrm{ex}=350$ $\mathrm{nm}, \lambda \mathrm{em}=466 \mathrm{~nm}$.

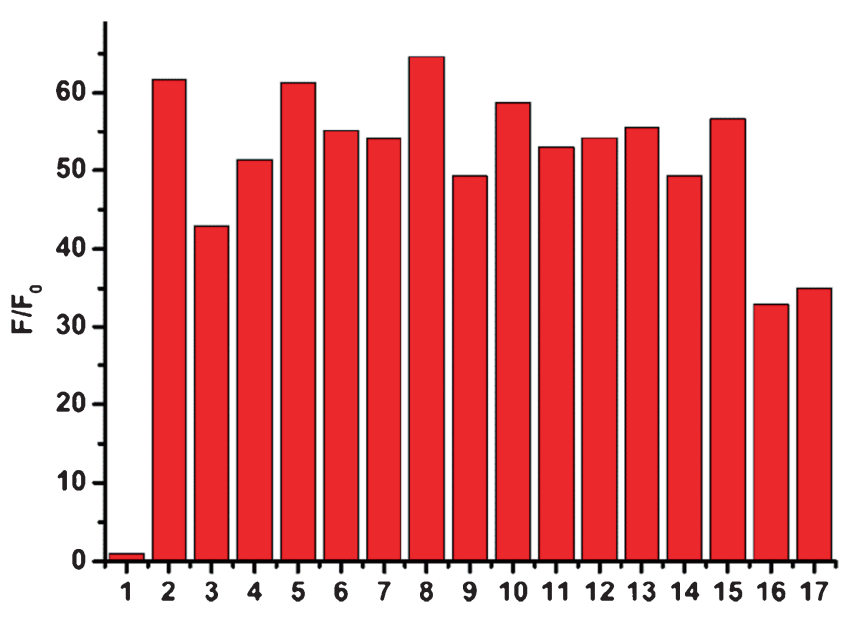

Figure 3. Fluorescence response of probe $\mathbf{1}(5 \mu \mathrm{M})$ upon addition of various species in the presence of sulfide in PBS buffer (10 mM, pH7.4,containin1 mM CTAB). $\lambda$ ex $=350$ $\mathrm{nm}, \lambda \mathrm{em}=466 \mathrm{~nm}$. (1) probe, (2) $\mathrm{S}^{2-}$, (3) $\mathrm{SO}_{3}^{2-}+\mathrm{S}^{2-}$, (4) $\mathrm{SO}_{4}^{2-}+\mathrm{S}^{2-}$, (5) $\mathrm{SCN}^{-}+\mathrm{S}^{2-}$, (6) $\mathrm{F}^{-}+\mathrm{S}^{2-}$, (7) $\mathrm{Cl}^{-}+\mathrm{S}^{2-}$, (8) $\mathrm{Br}^{-}+\mathrm{S}^{2-}$, (9) $\mathrm{I}^{-}+\mathrm{S}^{2-}$, (10) $\mathrm{PO}_{4}^{3-}+\mathrm{S}^{2-}$, (11) $\mathrm{HPO}_{4}^{2-}+\mathrm{S}^{2-}$, (12) $\mathrm{AcO}^{-}+\mathrm{S}^{2-}$, (13) $\mathrm{HCO}_{3}^{-}+\mathrm{S}^{2-}$, (14) $\mathrm{N}_{3}^{-}+\mathrm{S}^{2-}$, (15) $\mathrm{C}_{2} \mathrm{O}_{4}^{2-}+\mathrm{S}^{2}$, (16) $\mathrm{Cys}+\mathrm{S}^{2-}$, (17) $\mathrm{GSH}+\mathrm{S}^{2-}$.

strong fluorescence response upon addition of 5 eq. of $\mathrm{H}_{2} \mathrm{~S}$ in the presence of 100 eq. GSH and Cys. The good fluorescence recovery demonstrated the good selectivity for hydrogen sulfide.

\section{Conclusions}

A coumarin based, reaction-type fluorescent probe for detection of $\mathrm{H}_{2} \mathrm{~S}$ in aqueous solution was synthesized and explored through a two-step nucleophilic reaction. The probe exhibited high selectively towards $\mathrm{H}_{2} \mathrm{~S}$ and good anti-interference towards many anions. The sensing of $\mathrm{H}_{2} \mathrm{~S}$ was rapid and finished within 15 min with detection limit as $30 \mathrm{nM}$.

\section{Supplementary Information}

${ }^{1} \mathrm{H}$ NMR, ${ }^{13} \mathrm{C}$ NMR and ESI-Mass spectra of probe and figures $\mathrm{S} 1-\mathrm{S} 6$ are available at www.ias.ac.in/chemsci.

\section{Acknowledgement}

This work was financially supported by the National Science Foundation of China (91026022) and China Post-doctoral Science Foundation funded project (2014M560718).

\section{References}

1. (a) Moore P K, Bhatia M and Moochhala S 2003 Trends. Pharmacol. Sci. 24 609; (b) Wang R 2003 Antioxid. Redox. Signaling 5 493; (c) Szabó C 2007 Nat. Rev. Drug Discovery 6 917; (d) Li L, Rose P and Moore P K 2011 Annu. Rev. Pharmacol. Toxicol 51169

2. (a) Yang G, Wu L and Wang R 2006 FASEB J 20 553; (b) Li L, Bhatia M, Zhu Y Z, Zhu Y, Ramnath C R D, Wang Z J, Anuar F B, Whan M, Salto-Tellez M and Moore P K 2005 FASEB J 191196

3. Peng Y J, Nanduri J, Raghuraman G, Souvannakitti D, Gadalla M M, Kumar G K, Snyder S H and Prabhakar N R 2010 Proc. Natl. Acad. Sci. U.S.A. 10710719 
4. (a) Lippert A R, New E J and Chang C J 2011 J. Am. Chem. Soc. 133 10078; (b) Peng H J, Cheng Y F, Dai C F, King A L, Predmore B L, Lefer D J and Wang B H 2011 Angew. Chem. Int. Ed. 50 9672; (c) Lin V S, Lippert A R and Chang C J 2013 Proc. Natl. Acad. Sci. U.S.A. 110 7131; (d) Mao G J, Wei T T, Wang X X, Huan S Y, Zhang D Q, Lu J, Zhang X B, Tan W H, Shen G L and Yu R Q 2013 Anal. Chem. 85 7875; (e) Bae S K, Heo C H, Choi D J, Sen D, Joe E H, Cho B R and Kim H M 2013 J. Am. Chem. Soc. 135 9915; (f) Yu F, Li P, Song P, Wang B, Zhao J and Han K 2012 Chem. Commun. 482852

5. (a) Xuan W, Pan R, Cao Y T, Liu K J and Wang W 2012 Chem. Commun. 48 10669; (b) Wang R, Yu F B, Chen L X, Chen H, Wang L J and Zhang W W 2012 Chem. Commun. 48 11757; (c) Montoya L A and Pluth M D 2012 Chem. Commun. 48 4767; (d) Wu M Y, Li K, Hou J T, Huang Z and Yu X Q 2012 Org. Biomol. Chem. 10 8342

6. (a) Sasakura K, Hananoka K, Shibuya N, Mikami Y, Kimura Y, Komatsu T, Ueno T, Terai T, Kimura H and Nagano T 2011 J. Am. Chem. Soc. 133 18003; (b) Choi M G, Cha S, Lee H, Jeon H L and Chang S K 2009 Chem. Commun. 7390; (c) Hou F P, Huang L, Xi P X, Cheng J, Zhao X F, Xie G Q, Shi Y J, Cheng F J, Yao X J, Bai D C and Zeng Z Z 2012 Inorg. Chem. 51 2454; (d) Cao X W, Lin W Y and He L W 2011 Org. Lett. 13 4716; (e) Wang M Q, Li K, Hou J T, Wu M Y, Huang Z and Yu X Q 2012 J. Org. Chem. 778350

7. (a) Wang J L, Lin W Y and Li W L 2013 Biomaterials 34 7429; (b) Cao X W, Lin W Y, Zheng K B and He L W 2012 Chem. Commun. 48 10529; (c) Liu T Y, Xu Z C, Spring D R and Cui J G 2013 Org. Lett. 152310

8. Kumar N, Bhalla V and Kumar M 2013 Coord. Chem. Rev. 2572335

9. (a) Chen Y C, Zhu C C, Yang Z H, Chen J J, He Y F, Jiao Y, He W J, Qiu L, Cen J J and Guo Z J 2013 Angew. Chem. Int. Ed. 52 1688; (b) Qian Y, Karpus J, Kabil O, Zhang S Y, Zhu H L, Banerjee R, Zhao J and He C 2011
Nat. Commun. 2 495; (c) Chen W, Liu C R, Peng B, Zhao Y, Pacheco A and Xian M 2013 Chem. Sci. 4 2892; (d) Qian Y, Zhang L, Dig S T, Deng X, He C, Zheng X E, Zhu H L and Zhao J 2012 Chem. Sci. 3 2920; (e) Zhang J Y, Sun Y Q, Liu J, Shi Y W and Guo W 2013 Chem. Commun. 49 11305; (f) Chen X, Wu S, Han J and Han S 2013 Bioorg. Med. Chem. Lett. 23 5295; (g) Qian Y, Yang B, Shen Y, Du Q, Lin L, Lin J and Zhu H 2013 Sens. Actuators B: Chem. 182 498; (h) Li X, Zhang S, Cao J, Xie N, Liu T, Yang B, He Q and Hu Y 2013 Chem. Commun. 49 8656; (i) Xu Z, Xu L, Zhou J, Xu Y, Zhu W and Qian X 2012 Chem. Commun. 48 10871; (j) Liu C, Peng B, Li S, Park C M, Whorton A R and Xian M 2012 Org. Lett. 14 2184; (k) Wang X, Sun J, Zhang W, Ma X, Lv J and Tang B 2013 Chem. Sci. 42551

10. (a) Jung H S, Han J H, Habata Y, Kang C and Kim J S 2011 Chem. Commun. 47 5142; (b) Helal A, Or Rashid M H, Choi C H and Kim H S 2011 Tetrahedron 67 2794; (c) Yuan L, Lin W, Song J and Yang Y 2011 Chem. Commun. 4712691

11. Li K, Xu H R, Yu K, K, Hou J T and Yu X Q 2013 Anal. Methods 52653

12. Lin W, Yuan L, Feng J and Cao X 2008 Eur. J. Org. Chem. 162689

13. Niikura K and Anslyn E V 2003 J. Org. Chem. 68 10156; (b) Mallick A, Mandal M C, Haldar B, Chakrabarty A, Das P and Chattopadhyay N 2006 J. Am. Chem. Soc. 128 3126; (c) Zhao Y and Zhong Z 2006 Org. Lett. 8 4715; (d) Wang J, Qian X, Qian J and Xu Y 2007 Chem. Eur. J. 13 7543; (e) Uchiyama S, Iwai K and de Silva A P 2008 Angew. Chem. Int. Ed. 47 4667; (f) Fan J, Wang Z, Zhu H, Fu N 2013 Sens. Actuators B: Chem. 188 886; (g) Tian H, Qian J, Sun Q, Bai H and Zhang W 2013 Anal. Chim. Acta 788 165; (h) Xu Y, Li B, Xiao L, Li W, Zhang C, Sun S and Pang Y 2013 Chem. Commun. 49 7732; (i) Reddy G U, Ramu V, Roy S, Taye N, Chattopadhyay S and Das A 2014 Chem. Commun. 50 14421; (j) Praveen L, Saha S, Jewrajka S K and Das A 2013 J. Mater. Chem. B 11150 